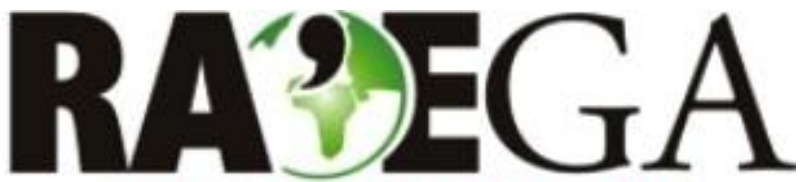

O ESPACO GEOGRÁFICO EM ANÁLISE

\title{
USO DO TERRITÓRIO NA REGIÃO METROPOLITANA DE CAMPINAS: O QUE SE MOSTRA NO INVENTÁRIO DA CULTURA HIP HOP (2005)
}

\section{USE OF TERRITORY IN THE METROPOLITAN REGION OF CAMPINAS: WHAT SHOWS THE INVENTORY OF HIP HOP CULTURE (2005)}

\author{
Cristiano Nunes Alves \\ Doutorando em Geografia pela Universidade Estadual de Campinas (UNICAMP) \\ Instituto de Geociências \\ Campinas, $S P$ \\ e-mail: cris7cris7@yahoo.com.br
}

\section{Recebido em: 13/09/2013}

Aceito em: 03/03/2014

\section{Resumo}

Problematiza-se a metropolização corporativa na Região Metropolitana de Campinas a partir do estudo do uso do território pelo circuito hip hop. Primeiramente, aborda-se o contexto de periferização e segregação da metrópole campineira. Em seguida, destaca-se o inventário da cultura hip hop na Região, constituído por informações primárias reunidas entre os anos de 2003 e 2005. O inventário assinala a existência de cerca de 300 grupos de rap, o que corresponde a cerca de mil pessoas cantando o gênero musical da cultura hip hop, além de apontar a ação de cerca de 250 grafiteiros e dançarinos de break espalhados por catorze cidades da Região. $\mathrm{O}$ circuito envolve órgãos articuladores, rádios livres, lojas de artigos hip hop e estúdios fonográficos, entre outros. Observa-se a aproximação de parte dos militantes do hip hop com partidos políticos, num exemplo da cultura tornada movimento institucionalizado. A manifestação dos elementos do hip hop dá-se basicamente nas periferias da Região em especial nas cidades de Campinas, Sumaré e Hortolândia. Destaca-se o uso do espaço público como tática primeira da cultura das ruas, num calendário que propicía o encontro de diferentes agentes periféricos em seus eventos artísticos. Almeja-se refletir sobre as alternativas para o estudo dos circuitos culturais no território usado, acredita-se, uma maneira de melhor compreender a dinâmica urbana contemporânea.

Palavras-chave: Espaço Urbano; Periferia; Lugar; Arte; Cultura Das Ruas. 


\title{
ALVES, C.N. \\ Uso do território na região metropolitana de Campinas: o que se mostra no inventário da cultura hip hop (2005)
}

\begin{abstract}
Problematize the corporate metropolization in the Metropolitan Region of Campinas from the study of the use of the territory by the hip hop circuit. First approach the context of segregation and peripherization of Campinas. Then highlight the inventory of hip hop culture in the region, consisting of primary informations collected between the years 2003 and 2005. The inventory indicates that there about 300 rap groups, which corresponds to about a thousand people singing the musical genre of the hip hop, while pointing out the action about 250 graffiti artists and break dancers diffused in fourteen cities in the region. The circuit involves articulating institutions, free radio stations, hip hop goods shops, phonographic studios, among others. Observe the approach of the militants of hip hop, with political parties, a culture made such a movement institutionalized. The demonstration of the elements of hip hop occurs primarily in the peripheries in the region especially in the cities of Campinas, Sumaré and Hortolândia. Noteworthy is the use of public space as a major tactic of the street culture, a calendar favorable to the encounter of different peripherals agents in their artistic events. Reflect on the alternatives for the study of cultural circuits in the used territory, a way to better understand the contemporary urban dynamics.
\end{abstract}

Keywords: Urban Space; Periphery; Place, Art, Street Culture.

\section{INTRODUÇÃO}

Reivindicatória por excelência, a cultura hip hop se mostra um dos importantes meios de expressão de agentes periféricos de todo o mundo, que utilizam a arte em sua forma política para questionar a segregação a que são submetidos.

No Brasil, em especial nas duas últimas décadas, o hip hop dinamiza um circuito que se tornou componente integrante do espaço geográfico ${ }^{1}$, conformou e se apropriou de um sistema material para desenvolver suas atividades, tais como casas de shows, rádios livres, lojas especializadas, entre outros, além de usar fixos públicos, tais como escolas, parques e praças e uma série de objetos técnicos, desde bombas de grafite até receptores de rádio. Suas ações configuram igualmente

\footnotetext{
${ }^{1}$ No estudo da cultura hip hop na Região de Campinas, parte-se da definição de espaço geográfico proposto por Santos (1988, p. 16), como sendo "um conjunto indissociável do qual participam, de um lado, um certo arranjo de objetos geográficos, objetos naturais e objetos sociais e, de outro lado, a vida que os anima ou aquilo que Ihes dá vida. Isto é a sociedade em movimento" Importa apurar a organização do espaço (ISNARD, 1978), o resultado e condicionante de um projeto social, conflitante e processual. Debruça-se, assim, sobre a dinâmica das cidades da RMC, objetos de estudo (LENCIONI, 2008), os quais a partir do hip hop pretende-se melhor compreender em seu funcionamento.
} 


\section{ALVES, C.N. \\ Uso do território na região metropolitana de Campinas: o que se mostra no inventário da cultura hip hop (2005)}

um sistema, indissociado do sistema material, movido por seus militantes, e manifesto, entre outros elementos, pelo fluxo de informações do circuito hip-hop, envolvimento com projetos comunitários, estúdios para gravação, shows de rap, apresentações de break, grafitagem, calendário de eventos, entre outros.

Nesse período, a Região Metropolitana de Campinas (RMC) ganha vulto como um dos destaques do hip hop nacional. No intuito de contribuir para o entendimento do uso do território pelos circuitos culturais no período contemporâneo, busca-se analisar a espessura do circuito hip hop que se constituiu na Região, bem como a relação deste circuito com a desigualdade socioterritorial em curso na metrópole campineira.

Para a realização da pesquisa, além do levantamento bibliográfico e documental sobre a temática, em livros, periódicos, teses, material cartográfico, cartazes, discos, entre outros, foram fundamentais as informações primárias. Os elementos constituintes do Inventário Hip Hop, foram obtidos em uma série de trabalhos de campo realizados em 14 cidades da RMC entre os anos de $2003 \mathrm{e}$ 2005. Trata-se de informações primárias decorrentes de visitas técnicas a locais conformados e/ou apropriados pelo circuito: estúdios fonográficos, emissoras de rádios, casas de show, centros comunitários, entre outros; e entrevistas com uma série de agentes ligados ao hip hop: rappers, grafiteiros, breakers, produtores, articuladores, entre outros.

O presente artigo se estrutura da seguinte maneira: esta breve introdução é seguida pela problematização do tema, item no qual se destaca a cultura hip hop em sua relação com o lugar. Num segundo momento, se oferece ao leitor um panorama da Região de Campinas, destacando a desigualdade socioterritorial e as periferias urbanas dessa metrópole. Em seguida, apresenta-se uma síntese do inventário hip hop, um esforço de sistematização, no sentido de pensar a um só tempo o uso do território e os circuitos culturais na RMC. Por fim, destaca-se o uso do espaço público pelo hip hop na metrópole campineira, pondo em relevo o calendário em torno dos eventos artísticos da cultura das ruas na Região.

Acredita-se na importância de compreender a geografização das práticas culturais na cidade contemporânea e as possibilidades de articulação estético- 


\section{ALVES, C.N. \\ Uso do território na região metropolitana de Campinas: o que se mostra no inventário da cultura hip hop (2005)}

política nas periferias urbanas. Ao que tudo indica trata-se de um tema pouco desenvolvido nos estudos geográficos a respeito da metrópole campineira.

\section{PROBLEMATIZANDO A CULTURA HIP HOP NO TERRITÓRIO: O LUGAR E AS DIFERENTES TEMPORALIDADES NA CIDADE.}

Também conhecido como cultura das ruas, o hip hop ${ }^{2}$ hoje uma linguagem mundializada (ANDRADE, 1996; CALOGIROU, 1996; BÉTHUNE, 2002; GOMES, 2012) surge em fins da década de 1960 , momento em que jovens periféricos das cidades passam a questionar sistematicamente a segregação socioterritorial na qual se encontravam. Tais ações de resistência por parte dos hip hoppers, os militantes dessa cultura, constituem-se na indissociabilidade de três manifestações artísticas de caráter urbano: o rap (Expressão musical), o break (expressão corpórea) e o grafite (expressão visual).

Considerado a arte de persuasão, da mudança de consciência, o rap é um estilo musical que por meio de narrativas em rimas faladas, conclama o engajamento para a luta e assim, representa hoje uma pulsante voz da periferia marginalizada ${ }^{3}$.

A expressão corporal do movimento é dada pelo break, um tipo de dança que se mistura a golpes de artes marciais. O break foi incorporado ao hip hop como alternativa para a luta entre gangues, que foram substituídas por combates de dança: as batalhas. Os dançarinos de break se organizam em crews (grupos) e são chamados de breakers: b. boys (os homens) e b.girls (as mulheres).

O Grafite, por sua vez é o elemento que corresponde à expressão visual do hip hop, um estilo de pintura que aparece em diversos fragmentos de espaços urbanos, tais como viadutos, muros, vagões de trens, entre outros. Sua manifestação representa uma invasão simbólica dos segregados, que por meio das imagens transmitem as suas mensagens para a cidade. De maneira semelhante ao break, a organização dos grafiteiros frequentemente ocorre a partir das crews.

\footnotetext{
${ }^{2}$ Keyes (1996) explica que o termo hip hop é uma expressão popular relativa à dança que continha os movimentos de salto (hip) e de balanço dos quadris (hop).

${ }^{3}$ Os rappers desenvolvem a sua arte a partir dos grupos, constituídos pelo $M C$ (mestre de cerimônias), e pelo $D J$ (Disc Jóquei), responsáveis, respectivamente, pelo canto e pela parte instrumental do rap. Para saber mais sobre a origem do rap consultar Silva (2007) e Rubin (2004).
} 


\section{ALVES, C.N. \\ Uso do território na região metropolitana de Campinas: o que se mostra no inventário da cultura hip hop (2005)}

Silva (1998, p. 11) lembra que "a principal característica da cultura hip hop é o fato de estar imersa na experiência local". No lugar, uma das categorias de análise do espaço geográfico, tem-se a esfera da proximidade, da convivência e da contiguidade entre os coletivos humanos: um espaço de síntese e coabitação (MOREIRA, 2007). Tais elementos permitem estabelecer uma vida comum, sob a qual se edificam valores, normas e solidariedades mais ligadas à troca, à espontaneidade e à criatividade (SANTOS, 1999), elementos intrínsecos ao fazer hip hop.

Com espessuras constituídas no mundo vivido coerentes com um sistema de eventos geografizados (SILVEIRA, 1999) o lugar dá luz a uma integração mais orgânica entre os agentes, sendo uma dimensão apropriada para se compreender o espaço banal, compartilhado por todos os atores: hegemônicos e hegemonizados. Tratar-se-ia de uma entrada frutífera para o estudo do circuito em torno da cultura das ruas.

A mediação entre o lugar, a comunidade próxima e os integrantes do movimento hip hop tem nas posses um dos elementos centrais, pois possibilita ações nos planos político, cultural e comunitário. Andrade (1996) define as posses como associações locais em que os militantes do hip hop procuram reelaborar a realidade conflitiva das ruas em termos da cultura e do lazer. De acordo com a autora supracitada, essas associações, em geral, reúnem grupos de rap, breakers e grafiteiros com o objetivo de promover "o aperfeiçoamento artístico dos elementos do hip hop e divulgação dessa cultura de rua em sua autenticidade" (ANDRADE, 1996, p. 162).

São inúmeros os exemplos da ligação do hip hop com o lugar. Nas letras dos raps há a apresentação de personagens do cotidiano da periferia, tais como a polícia despreparada, a mãe que sofre com o filho envolvido com o crime, o traficante e as suas normas ou o trabalhador e a negação de seus direitos. Tem-se ainda a descrição do entorno, seus aspectos e problemas, como a falta d'água, de lazer, de educação, os códigos de ética, a localização dentro da cidade, entre outros. As manifestações do break e do grafite também trazem referências ao lugar, com a pintura de imagens que fazem parte do cotidiano da periferia, ou a adoção do nome do local de origem pelas crews. 
Uso do território na região metropolitana de Campinas: o que se mostra no inventário da cultura hip hop (2005)

A manifestação dos segregados, força motriz da cultura hip hop, pode ser entendida pelas noções de tempo lento e tempo rápido, propostas por Santos (1994, 2002). O autor supracitado explica que o tempo rápido é o tempo das firmas, das instituições e dos indivíduos hegemônicos e que os atores hegemonizados vivem no tempo lento ${ }^{4}$.

Segundo Santos (1994, p. 81), "a força dos fracos é seu tempo lento". Os homens do tempo lento, que residem em áreas desprovidas de bens e serviços sociais, esquecidos pelos poderes públicos devido a sua imobilidade econômica diante da globalização, acabam por serem "mais velozes na descoberta do mundo", residindo aí a sua força (Idem, p. 84-85).

A forte imersão do hip hop no lugar confere a esta cultura a condição de ser uma das principais expressões das periferias das cidades brasileiras desde meados dos anos 1980. O presente inventário demonstra que a presença do hip hop torna-se latente na RMC, sobretudo nas últimas duas décadas. Como se vê a cultura das ruas figura como um dos elementos modeladores da aglomeração campineira, essencialmente uma metrópole corporativa.

\section{APRESENTANDO A METRÓPOLE CORPORATIVA: A DESIGUALDADE SOCIOTERRITORIAL NA RMC}

Lourenço (2002, p. 1), pontua que malgrado a difusão do hip hop por todo o mundo, "alguns lugares foram propícios ao seu desenvolvimento, devido às condições de miséria e pobreza de sua periferia" o que implica no seguinte lema: "onde existe periferia existe hip hop". Ora, o Brasil - vale lembrar - numa tendência do chamado terceiro mundo, é um país cuja urbanização é marcada por um processo de periferização, observado especialmente nas grandes aglomerações urbanas, caso da Região de Campinas. Nessa via, Santos (1989, 1990), explica que nos países subdesenvolvidos, em virtude das peculiaridades de sua história, "os problemas são ampliados... e os remédios com freqüência se impõem como novos problemas" o que causa desesperança quanto a soluções adequadas (SANTOS, 1990, p. 9). O autor supracitado afirma que nas últimas décadas as metrópoles

\footnotetext{
${ }^{4}$ Vale lembrar que os tempos serão diferentes de lugar para lugar e dizem respeito não aos objetos técnicos em si, mas às ações que os animam (SANTOS, 2002).
} 


\section{ALVES, C.N. \\ Uso do território na região metropolitana de Campinas: o que se mostra no inventário da cultura hip hop (2005)}

trabalham em compasso com o ritmo do mundo, evoluindo de acordo com premissas globais, em detrimento de sua história local e suas especificidades.

A subordinação aos interesses de uma economia neoliberal engendra uma série de variáveis que fazem da metrópole contemporânea um lugar em que os direitos se tornem privilégios para a imensa maioria da população, fazendo-se necessário considerar estas variáveis na análise metropolitana (SANTOS, 1990). Para denominar esse espaço que se amplia com base no interesse hegemônico, Santos (1989) propõe a ideia de metrópole corporativa ${ }^{5}$.

De maneira semelhante Lojkine (1977), pondera que "as contradições sociais políticas da urbanização capitalista" (Idem, p. 36) fundamentam-se no conflito entre o que exige o capital e o que exige o coletivo citadino. Disso decorre que os meios (bens e serviços) necessários à reprodução do capital como os relacionados à fluidez, sejam privilegiados pelo Estado em relação "aos meios de consumo coletivo" (Ibidem, p. 161), denominados pelo autor supracitado como meios "supérfluos" para o capital, já que implicam apenas na reprodução da força de trabalho, tais como os meios ligados à educação, saúde ou lazer. Também nesse sentido, Corrêa (1989, p. 26) afirma que a atuação do Estado ocorre, sobretudo, "visando criar condições de realização e reprodução da sociedade capitalista, isto é, condições que viabilizam o processo de acumulação e a reprodução das classes sociais e suas frações." Por seu turno, Rochefort (2003, p. 117), considera o Brasil "um país complicado" no que se refere aos caminhos para um crescimento que venha a trazer o desenvolvimento para a população, reduzindo as desigualdades socioterritoriais que historicamente acompanham sua formação socioespacial, seja por meio de regionalizações baseadas em estudos aprofundados ou, seja por meio de um planejamento mais equilibrado.

\footnotetext{
${ }^{5}$ Em sua reflexão, Santos $(1989,1990)$ pontua a importância analítica do papel do Estado na distribuição de renda e os contrastes decorrentes, no papel da especulação e dos vazios urbanos, na imobilidade relativa dos pobres, na fragmentação metropolitana e no problema do gasto público seletivo socioterritorialmente (Idem, $p$. 10). O autor supracitado chama atenção ainda para a importância do atrelamento à realidade no trabalho geográfico, lembrando que "a própria cidade, como materialidade, tem de ser colocada na frente da cena, por que ela se impõe aos demais figurantes como uma estrutura de enquadramento - isto é, um dado dinâmico -, sem a qual (...) a própria vida social dificilmente pode ser entendida".(Ibidem, p. 11). A partir da análise conjunta de tais elementos e tomando a Região Metropolitana de São Paulo como situação estudada, Santos (1990) se depara com uma metrópole concentradora de equipamentos de bens e serviços, excludente e que serve, sobretudo, aos interesses hegemônicos das grandes empresas (as grandes corporações) que, quase sempre com o aval do Estado, operam no espaço urbano apoiados em orçamentos públicos que deixam o social em segundo plano.
} 
Uso do território na região metropolitana de Campinas: o que se mostra no inventário da cultura hip hop (2005)

Observa-se o rebatimento dessa problemática na regionalização instituída em torno de Campinas. A Lei Complementar no 870, de 19 de junho de 2000, estabelece as normas que presidem o funcionamento da Região Metropolitana de Campinas - RMC (Figura 1). A regionalização, que tem a cidade de Campinas como núcleo, compreende 19 municípios, numa área considerada um dos maiores polos tecnológicos do país, inserida no que a EMPLASA ${ }^{6}$ chama de complexo metropolitano expandido, que corresponde às regiões metropolitanas de São Paulo, Campinas e Baixada Santista.

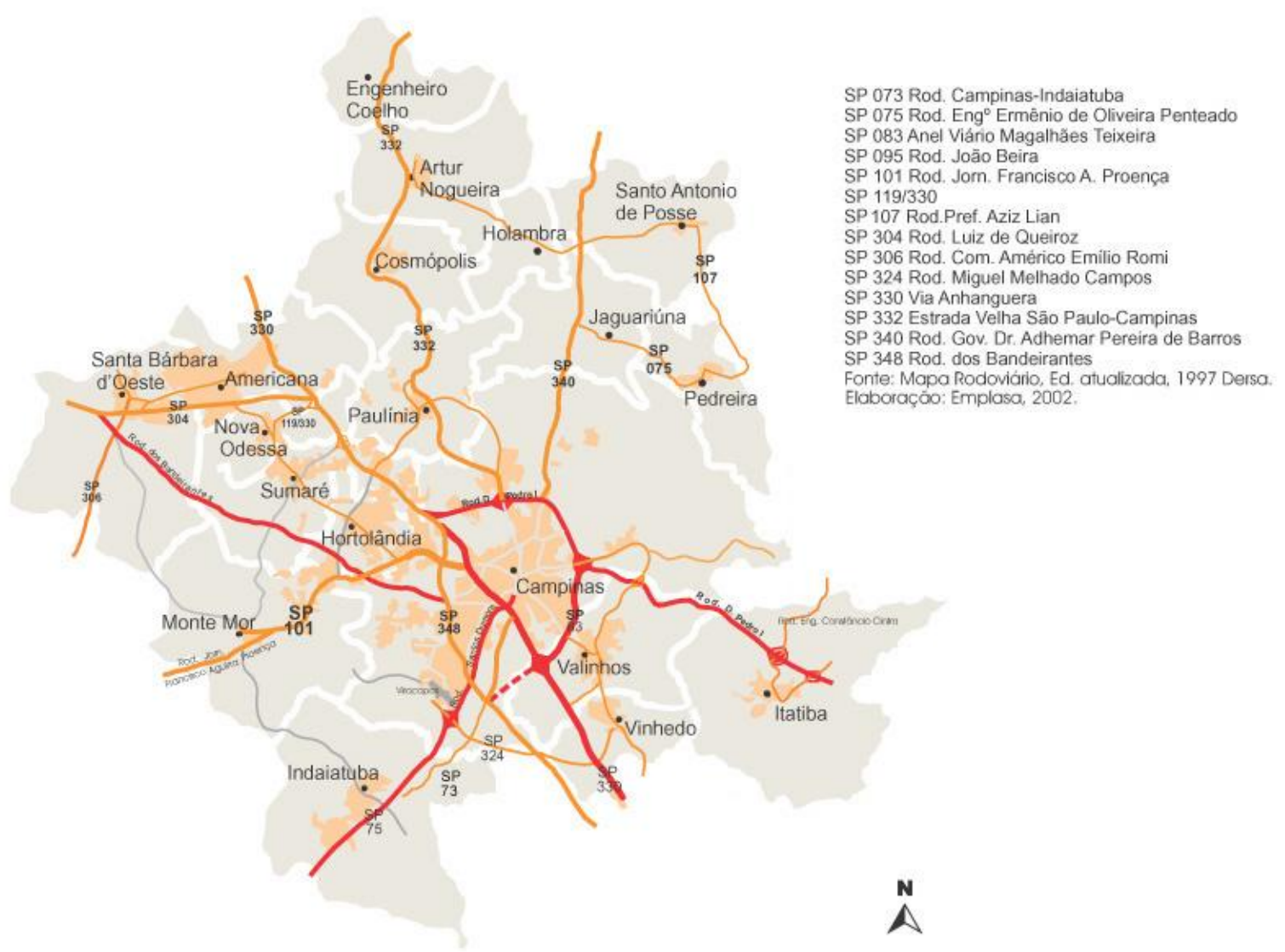

Figura 1: A Região Metropolitana de Campinas Fonte: sítio da EMPLASA

Concentrando hoje em torno de 7\% da população estadual, a RMC nos últimos quarenta anos teve sua população aumentando de 680.826 habitantes para

\footnotetext{
${ }^{6}$ Empresa Paulista de Planejamento Metropolitano S/A, órgão responsável pelo planejamento urbano na RMC.
} 


\section{ALVES, C.N. \\ Uso do território na região metropolitana de Campinas: o que se mostra no inventário da cultura hip hop (2005)}

2.866.453 habitantes (IBGE, estimativa, 2012) ${ }^{7}$. Durante as décadas de $1970 \mathrm{e}$ 1980, a área abrigou intensos fluxos imigratórios ${ }^{8}$ e assim como outras metrópoles brasileiras, passou por uma urbanização acelerada, intensificando o processo de segregação-fragmentação que historicamente acompanhou a sua trajetória urbana.

Cano e Brandão (2002, p. 124), afirmam que a evolução da mancha urbana campineira "sempre esteve articulada a interesses da elite local" assim como a legislação urbanística, os mecanismos de especulação e orçamentos públicos comprometidos com empresas hegemônicas, levando a formação de um espaço urbano fragmentado e segregado.

A segregação-fragmentação, característica da cidade de Campinas, ganha contornos ainda mais marcantes na conurbação com os municípios vizinhos, configurando dois eixos metropolitanos: um em que predominam populações de baixa renda e outro, residindo, grosso modo, às populações de rendas média e alta. Caiado (2002), caracteriza tais eixos da seguinte maneira:

A ocupação urbana periférica de baixa renda consolidou-se principalmente no vetor sudoeste com a incorporação de áreas situadas além da rodovia Anhanguera, com a cidade expandindo-se na direção de Sumaré, Hortolândia, Monte Mor e Indaiatuba. No eixo ao longo da Via Anhanguera, a principal característica é a quase inexistência de descontinuidade na ocupação, configurando uma mancha urbana que se estende de Vinhedo até Americana, articulando fortemente a vida urbana dos municípios situados nesse eixo (CAIADO, 2002, p. 124).

Enquanto que:

Na direção de Barão Geraldo e nas cidades de Paulínia e Jaguariúna, o eixo norte-nordeste é outro forte vetor de expansão urbana, este destinado à habitação das camadas de renda média e alta e a localização de indústrias e centros de pesquisa de alta tecnologia (EMBRAPA, Sofitex, Laboratório de Luz Síncroton) e de grandes centros de consumo de porte regional (shopping centers, hipermercados, casas noturnas e outros) (CAIADO, 2002, p.124).

\footnotetext{
${ }^{7}$ Instituto Brasileiro de Geografia e Estatística.

${ }^{8}$ Cano e Brandão (2002) lembram que em decorrência do crescimento populacional, ocorreu já na década de 1970 a formação dos primeiros eixos periféricos, estendendo-se em torno do município sede de Campinas, pelas cidades de Sumaré, Santa Bárbara D'Oeste e Americana. O fenômeno estender-se-ia a outros municípios da RMC na década de 1980.
} 


\section{ALVES, C.N. \\ Uso do território na região metropolitana de Campinas: o que se mostra no inventário da cultura hip hop (2005)}

Nessa via, lembra-se Silva (1998, p. 132), para quem, na cultura hip hop, a periferia não é apenas uma referência geográfica. $O$ pertencimento à periferia significa "ser jovem pobre, preto, branco ou pardo, ou seja, socialmente excluído". Os hip hoppers bem sabem que habitam espaços opacos (SANTOS, 1994), lugares esquecidos pelo poder público e onde as possibilidades do período atual, existem mais como miragens.

No bojo do processo de fragmentação-segregação, verificam-se os processos de favelização e periferização, acentuados à medida que se acelera a urbanização na metrópole, fenômeno observado em quase todos os municípios da RMC, independente do seu tamanho ${ }^{9}$.

\section{OS LUGARES DO TEMPO LENTO NA RMC: DE ONDE VEM A CORRERIA ${ }^{10}$ DO HIP HOP.}

Mais uma vez numa tendência das metrópoles brasileiras, a periferização torna-se, em especial nas últimas décadas, um fenômeno crescente na RMC, isto é: disseminam-se as grandes aglomerações humanas no período. Bairros que simplesmente não existiam, hoje comportam enormes contingentes populacionais. São esses lugares que "expressam formas de uso do território historicamente assentadas em polarizações e privilégios" (MESTRE e FONSECA, 2011, p. 34), os abrigos da cultura hip hop na Região.

Em Indaiatuba surge o Bairro Morada do Sol, que conta hoje com cerca de 60 mil pessoas (quase $40 \%$ da população do município). Em Santa Bárbara d'Oeste, instala-se a "Zona Leste", na divisa com Americana, hoje abrigando aproximadamente 70 mil pessoas (cerca de metade da população barbarense). Em

\footnotetext{
${ }^{9}$ Dados da Prefeitura Municipal de Campinas indicam que no período 1991-1996 o número de favelados na cidade aumentou de 63 mil para 88 mil, o que corresponde a um crescimento de $7 \%$ ao ano do número de favelados, contra $1,4 \%$ do acréscimo populacional total. O processo de favelização na RMC não se restringe ao município núcleo: Americana, considerada uma das cidades com melhores condições de vida da Região, tinha 270 mil barracos no ano de 2000 (Prefeitura Municipal de Americana). No mesmo ano Hortolândia contava com 4.418 barracos e 53 loteamentos tidos como irregulares (Prefeitura Municipal de Hortolândia). Sumaré por sua vez, apresentava 68 núcleos de favelas em 2000, abrigando 7.108 famílias (Prefeitura Municipal de Sumaré). É importante lembrar que os dados sobre favelização fornecidos pelas prefeituras municipais, apesar de tomados como oficiais causam controvérsias, quando confrontados com dados apresentados pelos próprios citadinos, verificando-se em geral que os números oficiais são menores.

${ }^{10} \mathrm{O}$ termo é utilizado pelos hip hoppers para denominar as ações em si: o agir. Assim fala-se em fazer o corre, para desenvolver um projeto, seja a gravação de um CD, uma grafitagem, continuar estudando ou organizar de um evento artístico.
} 
Uso do território na região metropolitana de Campinas: o que se mostra no inventário da cultura hip hop (2005)

Americana, constitui-se o Bairro Antonio Zanaga, por muito tempo isolado do perímetro urbano.

Por sua vez, Sumaré, assim como Hortolândia, contam ambas as cidades com uma mancha urbana extremamente fragmentada, sob o qual se distribuem inúmeros bairros com características periféricas, como os Bairros Amanda e Rosolém em Hortolândia, ou Jardim Denadai, Bairro Picerno e o Matão, localizados em Sumaré, sendo este último uma grande aglomeração às margens da Rodovia Anhangüera na divisa com Campinas.

Cidade conhecida pelo grande número de condomínios de luxo, Vinhedo abriga o Bairro Capela, chamado pelos locais de "a Outra Vinhedo", devido a sua precariedade. De modo semelhante se pode citar Valinhos, Jaguariúna ou Pedreira, cujas paisagens exaltadas pelo marketing territorial, abrigam Bairros sem o mínimo de condições como Morro do Piolho em Pedreira, "o lugar escondido da própria cidade" relatam seus moradores. Para entender o exposto basta uma passagem pela estrada do Circuito das Águas que corta Jaguariúna e Pedreira: não se vê nada além das casas de alto padrão, estando as periferias fora deste percurso.

O mesmo não se pode dizer das margens da Rodovia Campinas-Monte Mor (SP-101), com um longo trecho em Monte Mor acompanhando bairros periféricos, distantes do centro da cidade, alocados nos dois lados da rodovia, visíveis por quem ali passa, mas invisíveis para o poder público.

Devido à magnitude, a periferização campineira talvez seja a que mais chame a atenção na RMC. Pelo eixo da Avenida John Boyd Dunlop, na porção sul da mancha urbana, estende-se praticamente quinze quilômetros de bairros periféricos, como os DICs, Jardim Florence, Campo Grande, Campo Belo e Satélite Íris, este último às margens da Rodovia do Bandeirantes, mas sem acesso a ela, sendo necessário para chegar ao Bairro, desvios de até dez quilômetros por dentro do perímetro urbano.

Percebe-se que os exemplos são infindáveis. Cabe agora perguntar o que têm em comum esses lugares. Além da precariedade na dotação de bens e serviços públicos e dificuldade de acesso físico e econômico desses por parte de seus moradores (características inerentes às periferias), esses lugares guardam outros aspectos em comum. 


\section{ALVES, C.N. \\ Uso do território na região metropolitana de Campinas: o que se mostra no inventário da cultura hip hop (2005)}

A grande parte de suas populações é migrante, seja de outros estados (como Paraná, Minas Gerais e estados do Nordeste), da capital paulista e do interior de São Paulo (grande parte do oeste do estado). Trata-se de bairros operários, com população trabalhando nas indústrias da Região, muitas delas localizadas no entorno dos bairros, nos distritos industriais.

Com poucas opções de lazer, seja no bairro ou na própria casa, a rua passa a ser mais frequentada, "as frentes das casas", assim com as igrejas e os botecos, que a despeito dos aspectos negativos da bebida alcoólica, trazem os efeitos positivos do diálogo, entre os jovens e os mais velhos. Desta feita, a grande quantidade de pessoas nas ruas das periferias, principalmente nos fins de semana contrasta com a pouca circulação nos bairros de classe média e alta.

Nos loteamentos populares predominam as construções de meio lote, em que terrenos em média com $250 \mathrm{~m}^{2}$ são repartidos entre os proprietários dando origem a duas casas, sendo comum a construção de casas menores nos fundos, por motivos diversos, como matrimônios precoces, chegada de parentes à cidade, entre outros. Em consequência disso, numa menor área se concentram mais residências. A construção de muitas casas em pequenas áreas caracteriza também os conjuntos habitacionais edificados sob a forma de casas ou prédios.

Não são raros os casos de pessoas que devido à falta de acessibilidade financeira, aliada a rotina de sobrevivência e, à carência do transporte coletivo, pouco saem dos seus bairros, afora o trajeto para o trabalho. Destacam-se em especial três fluxos de saída das populações periféricas de seus bairros:

- Em direção aos centros das cidades para consumir no circuito informal, seja em feiras, camelôs, ou lojas populares;

- Fluxos escolares, restritos aos jovens que continuam a estudar após o término do segundo grau (minoria), ou que ingressam em escolas técnicas, visto que, nos níveis anteriores, estes estudam nos próprios bairros ou em seu entorno;

- E, por fim, os fluxos para acessar bens e serviços de saúde, muitos deles intermunicipais, já que a maioria de tais bens e serviços se concentra em Campinas e Americana.

Vale lembrar, ainda como aspecto comum, o aumento do número de desempregados nesses lugares. Segundo dados dos censos demográficos do IBGE, 
Uso do território na região metropolitana de Campinas: o que se mostra no inventário da cultura hip hop (2005)

o desemprego da região, em 1991, representava $1,6 \%$ do desemprego estadual, atingindo cerca de 48 mil pessoas. Em 2000, o desemprego atingia mais de 173 mil pessoas, perfazendo $7,2 \%$ do desemprego estadual. Analisando a questão, Pochmann (2002, p. 149), lembra que "as políticas públicas metropolitanas para o emprego, a renda e a pobreza estão ainda por ser construídas". Tais políticas, apesar de urgentes, estão em segundo plano em detrimento do investimento logístico na Região.

Para finalizar, afirma-se que toda precariedade acima relatada, entremeia-se às potencialidades dadas pelo período atual e cristalizadas em diversos pontos como hotéis, condomínios de luxo, bairros de alto padrão e todo tipo de comodidades, expostas, seja pelo exame da paisagem, ou pela vasta propaganda que trazem consigo tais empreendimentos ligados aos grandes circuitos da economia.

\section{APRESENTANDO A SÍNTESE DO INVENTÁRIO HIP HOP: USO DO TERRITÓRIO E CIRCUITOS CULTURAIS NA REGIÃO DE CAMPINAS}

Apresenta-se a seguir um esforço de sistematização dos circuitos culturais no território usado. Sintetiza-se em um quadro o "Inventário do hip hop na Região Metropolitana de Campinas". Aspira-se balizar a reflexão em uma visão crítica do espaço geográfico, também "cartografável" sob o prisma da resistência (CRAMPTON e KRYGIER, 2006), deflagrando processos e fenômenos territoriais corriqueiramente ocultados.

Entende-se que a existência e a dinâmica de um circuito ganham significado quando analisadas as estratégias políticas no território usado, a categoria de análise, sinônimo de concretude e acontecer de sistemas de objetos e sistemas de ações no espaço geográfico, apontando para situações específicas a serem abordadas nos estudos geográficos (SANTOS, 1988). 
ALVES, C.N.

Uso do território na região metropolitana de Campinas: o que se mostra no inventário da cultura hip hop (2005)

\begin{tabular}{|c|c|c|c|c|c|c|c|c|c|c|c|}
\hline \multicolumn{12}{|c|}{$\begin{array}{l}\text { QUADRO SÍNTESE DO INVENTÁRIO HIP HOP } \\
\text { REGIÃO METROPOLITANA DE CAMPINAS (2005) }\end{array}$} \\
\hline \multirow{2}{*}{$\begin{array}{c}\begin{array}{c}\text { Elementos } \\
\text { do }\end{array} \\
\text { Inventário } \\
\text { Cidades }\end{array}$} & \multicolumn{3}{|c|}{$\begin{array}{c}\text { Agentes - Manifestação } \\
\text { dos elementos artísticos } \\
\text { do hip hop } \\
\text { (números aproximados) }\end{array}$} & \multicolumn{4}{|c|}{$\begin{array}{l}\text { Articulação e institucionalização do } \\
\text { movimento }\end{array}$} & \multicolumn{4}{|c|}{$\begin{array}{l}\text { Fixos acionados } \\
\text { pelo circuito hip hop }\end{array}$} \\
\hline & $\begin{array}{l}\text { Grupos } \\
\text { de } \\
\text { rap }\end{array}$ & $\begin{array}{l}\text { Crews de } \\
\text { break } \\
\text { Número de } \\
\text { breakers } \\
\text { (entre } \\
\text { parênteses) }\end{array}$ & $\begin{array}{l}\text { Crews de } \\
\text { grafite/ } \\
\text { Número de } \\
\text { grafiteiros } \\
\text { (entre } \\
\text { parênteses) }\end{array}$ & $\begin{array}{l}\text { Posses ou } \\
\text { Instituiçôes }\end{array}$ & $\begin{array}{l}\text { Número } \\
\text { médio de } \\
\text { eventos } \\
\text { públicos } \\
\text { por ano }\end{array}$ & $\begin{array}{l}\text { Ligação } \\
\text { do } \\
\text { movimento } \\
\text { com } \\
\text { partidos } \\
\text { políticos } \\
\text { e/ou } \\
\text { prefeituras }\end{array}$ & $\begin{array}{l}\text { Cidades } \\
\text { com maior } \\
\text { articulação } \\
\text { por parte da } \\
\text { militância } \\
\text { hip hop }\end{array}$ & $\begin{array}{l}\text { Rádios } \\
\text { livres }\end{array}$ & $\begin{array}{c}\text { Casas } \\
\text { de } \\
\text { shows }\end{array}$ & $\begin{array}{l}\text { Estúdios } \\
\text { Hip hop }\end{array}$ & $\begin{array}{l}\text { Lojas } \\
\text { de } \\
\text { artigos } \\
\text { hip hop }\end{array}$ \\
\hline Americana & 8 & $1(60)$ & (7) & $\begin{array}{l}\text { Projeto de } \\
\text { casa hip } \\
\text { hop em } \\
\text { andamento }\end{array}$ & 7 & $\begin{array}{l}\text { Apoio de } \\
\text { vereador } \\
\text { PCdoB }\end{array}$ & $\begin{array}{l}\text { Santa } \\
\text { Bárbara/ } \\
\text { Limeira }\end{array}$ & 1 & $\begin{array}{l}\text { Não } \\
\text { existe }\end{array}$ & 1 & 1 \\
\hline Campinas & 120 & $2(50)$ & $12(50)$ & $\begin{array}{l}\text { Casa do hip } \\
\text { hop//Posse } \\
\text { Rima \& } \\
\text { Cia/União } \\
\text { dos } \\
\text { Grafiteiros e } \\
\text { Conselho } \\
\text { hip hop }\end{array}$ & $\begin{array}{l}\text { Calendário } \\
\text { densoi } \\
\text { aleatorio }\end{array}$ & $\begin{array}{l}\text { Ligação } \\
\text { com } \\
\text { prefeitura/ } \\
\text { PT }\end{array}$ & $\begin{array}{l}\text { Hortolândia } \\
\text { Sumaré } \\
\text { Indaiatuba } \\
\text { Valinhos }\end{array}$ & 20 & $\begin{array}{l}\text { Não } \\
\text { existe }\end{array}$ & 2 & 4 \\
\hline Cosmópolis & 5 & (20) & (10) & Não existe & 8 & $\begin{array}{c}\text { Sem } \\
\text { informação }\end{array}$ & $\begin{array}{l}\text { Limeira } \\
\text { A. Nogueira }\end{array}$ & \multicolumn{4}{|c|}{ Não existe } \\
\hline Hortolândia & 25 & $\begin{array}{c}\text { Sem } \\
\text { informação }\end{array}$ & (6) & $\begin{array}{l}\text { Posse } \\
\text { Força } \\
\text { Cultural } \\
\end{array}$ & 10 & $\begin{array}{l}\text { Ligação } \\
\text { com } \\
\text { Prefeitura }\end{array}$ & $\begin{array}{l}\text { Sumaré } \\
\text { Monte Mor } \\
\text { Campinas }\end{array}$ & 1 & $\begin{array}{l}\text { Não } \\
\text { existe }\end{array}$ & 1 & $\begin{array}{l}\text { Não } \\
\text { existe }\end{array}$ \\
\hline Indaiatuba & 30 & 3 & $\begin{array}{l}\text { Sem } \\
\text { informação }\end{array}$ & $\begin{array}{l}\text { Projeto de } \\
\text { posse em } \\
\text { andamento }\end{array}$ & $\begin{array}{l}\text { Sem } \\
\text { Informação }\end{array}$ & $\begin{array}{l}\text { Ligação } \\
\text { com } \\
\text { Prefeitura }\end{array}$ & $\begin{array}{l}\text { Campinas } \\
\text { Monte Mor } \\
\text { Salto }\end{array}$ & 1 & \multicolumn{2}{|c|}{ Não existe } & 3 \\
\hline Jaguariúna & 4 & \multicolumn{2}{|c|}{ Sem informação } & Não existe & 5 & $\begin{array}{l}\text { Ligação } \\
\text { como } \\
\text { Prefeitura }\end{array}$ & $\begin{array}{l}\text { Pedreira } \\
\text { Amparo } \\
\text { Mogi Mirim }\end{array}$ & 1 & $\begin{array}{l}\text { Não } \\
\text { existe }\end{array}$ & 1 & $\begin{array}{l}\text { Não } \\
\text { existe }\end{array}$ \\
\hline Monte Mor & 8 & (20) & (3) & Não existe & 3 & $\begin{array}{l}\text { Não } \\
\text { existe }\end{array}$ & $\begin{array}{l}\text { Indaiatuba } \\
\text { Campinas } \\
\text { Hortolândia } \\
\end{array}$ & \multicolumn{4}{|c|}{ Não existe } \\
\hline $\begin{array}{c}\text { Nova } \\
\text { Odessa }\end{array}$ & 5 & \multicolumn{2}{|c|}{ Sem informação } & Não existe & 2 & $\begin{array}{c}\text { Sem } \\
\text { informação }\end{array}$ & Sumaré & & $\begin{array}{l}\text { Não } \\
\text { existe }\end{array}$ & 1 & $\begin{array}{l}\text { Não } \\
\text { existe }\end{array}$ \\
\hline Paulínia & 7 & \multicolumn{2}{|c|}{ Sem informação } & Não existe & $\begin{array}{c}\text { Sem } \\
\text { informaçäo }\end{array}$ & $\begin{array}{l}\begin{array}{c}\text { Não } \\
\text { existe }\end{array} \\
\end{array}$ & $\begin{array}{l}\text { Campinas } \\
\text { Cosmópolis }\end{array}$ & 1 & \multicolumn{3}{|c|}{ Não existe } \\
\hline Pedreira & 2 & (2) & (2) & Não existe & 8 & $\begin{array}{l}\text { Não } \\
\text { existe }\end{array}$ & $\begin{array}{l}\text { Jaguariúna } \\
\text { Amparo } \\
\text { Campinas }\end{array}$ & \multicolumn{4}{|c|}{ Não existe } \\
\hline $\begin{array}{l}\text { Santa } \\
\text { Bárbara } \\
\text { D’Oeste }\end{array}$ & 7 & (10) & $4(30)$ & $\begin{array}{l}\text { Projeto de } \\
\text { casa do hip } \\
\text { hop em } \\
\text { andamento }\end{array}$ & 6 & $\begin{array}{l}\text { Ligação } \\
\text { com } \\
\text { vereador } \\
\text { PCdoB }\end{array}$ & $\begin{array}{l}\text { Americana } \\
\text { Limeira } \\
\text { Campinas }\end{array}$ & 2 & 1 & $\begin{array}{l}\text { Não } \\
\text { existe }\end{array}$ & 1 \\
\hline Sumaré & 70 & 3 & 5 & $\begin{array}{l}\text { Articulação } \\
\text { junto à } \\
\text { Secretaria } \\
\text { Municipal } \\
\text { de Cultura }\end{array}$ & 8 & $\begin{array}{l}\text { Candidat } \\
\text { a ̀̀ } \\
\text { vereadora } \\
\text { militante } \\
\text { hip hop }\end{array}$ & $\begin{array}{l}\text { Hortolândia } \\
\text { Campinas }\end{array}$ & 2 & \multicolumn{3}{|c|}{ Não existe } \\
\hline Valinhos & 4 & \multicolumn{5}{|c|}{ Sem informação } & $\begin{array}{l}\text { Campinas } \\
\text { Vinhedo }\end{array}$ & \multicolumn{4}{|c|}{ Não existe } \\
\hline Vinhedo & 5 & 30 & $\begin{array}{l}\text { Sem } \\
\text { informação }\end{array}$ & Não existe & $\begin{array}{c}\text { Sem } \\
\text { informação }\end{array}$ & $\begin{array}{l}\text { Ligação } \\
\text { com } \\
\text { Prefeitura }\end{array}$ & $\begin{array}{l}\text { Louveira } \\
\text { Jundiaí }\end{array}$ & $\begin{array}{l}\text { Sem } \\
\text { informação }\end{array}$ & $\begin{array}{l}\text { Não } \\
\text { existe }\end{array}$ & 1 & $\begin{array}{l}\text { Não } \\
\text { existe }\end{array}$ \\
\hline Total & 290 & $9(162)$ & $21(78)$ & 7 & 49 & & & 28 & 1 & 7 & 9 \\
\hline
\end{tabular}

A análise do inventário aponta para a predominância do elemento rap em quase todas as cidades inventariadas, como o que conforma uma maior espessura em torno de si. Dos cerca de 290 grupos existentes nas 14 cidades da RMC inventariadas, aproximadamente 200 são abrigados em Campinas, Sumaré e 
Uso do território na região metropolitana de Campinas: o que se mostra no inventário da cultura hip hop (2005)

Hortolândia, cidades que contam com os seis órgãos ligados ao movimento hip hop. Tem-se nessas três cidades uma espécie de mancha hip hop, sinalizando para as maiores espessuras do circuito na RMC.

A produção fonográfica do rap na Região ocorre de maneira independente em estúdios especializados no gênero ou não. Os quatro estúdios especializados em rap funcionam nas casas dos próprios produtores (Figura 2) e operam com uma baixa densidade técnica-informacional embutida.

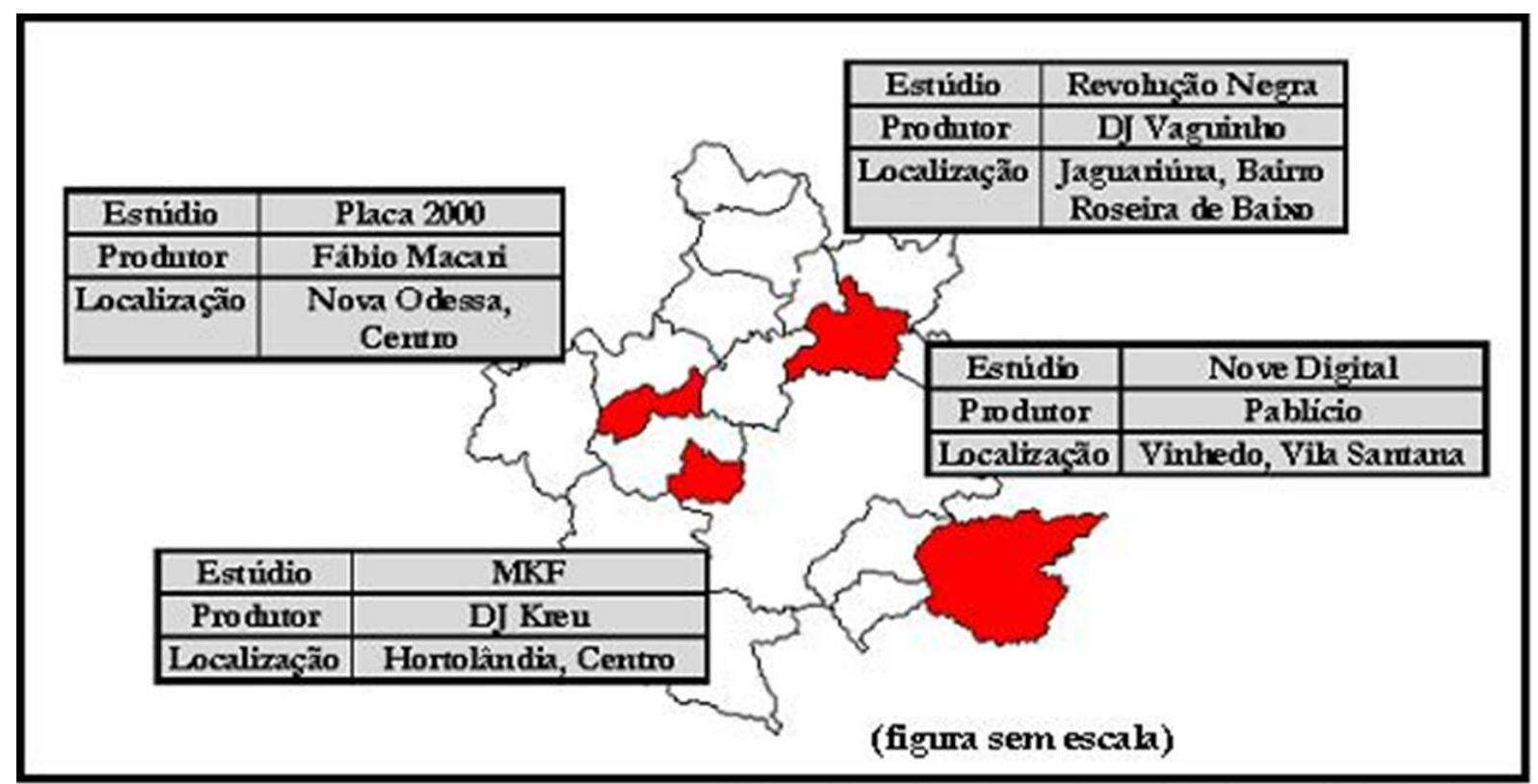

Figura 2: Distribuição dos estúdios especializados em hip hop na Região Metropolitana de Campinas (2005)

Elaboração Cartográfica: Cristiano N. Alves e Alcides M. Neto

Tais estúdios não mantém uma comunicação entre si, cada um produz músicas de grupos de várias cidades, em sua maioria do interior paulista. Em geral um estúdio polariza certo número de grupos da própria cidade e das cidades vizinhas, lógica que em muito se relaciona com o conhecimento prévio do produtor.

Pouco citadas na bibliografia sobre o rap, depara-se, no inventário, com as famílias: organizações entre grupos de rap, que desenvolvem ações em modelo cooperativo, visando em especial a promoção dos grupos que dela fazem parte, no que diz respeito à produção de rap, organização de eventos entre outros. Os integrantes das famílias afirmam que em torno destas organizações forma-se uma identidade, com os grupos agindo de maneira conjunta de acordo com valores como 
a autoestima ou o não uso de drogas. Em geral, as famílias contam com um grupo de rap que funciona como uma espécie de padrinho, em virtude de sua maior visibilidade ou tempo de carreira. Este grupo é responsável por divulgar grupos menores, e assim, sucessivamente, o circuito se expande.

Americana aparece como única cidade inventariada na qual o break é o elemento do hip hop predominante, com um circuito mais estruturado, ao lado de Campinas. O grafite também se destaca em Campinas, reunindo 17 das 21 crews inventariadas. Trata-se de um elemento presente em maior ou menor grau nas cidades da RMC, como demonstra a paisagem dessas urbes.

Sobre a institucionalização do "movimento", lembra-se que na quase totalidade das cidades da RMC, predomina uma aproximação do hip hop com partidos políticos e com o poder público, em geral na esfera municipal. Assim, os hip hoppers participam de campanhas eleitorais e até mesmo lançam seus próprios candidatos, caso de Eva Oliveira de Sumaré. A prática, que vem de longa data em Campinas, torna-se comum entre as cidades pesquisadas.

O movimento hip hop configura ainda uma rede com os seus próprios meios de comunicação, que engloba jornais, livros, zines, cartazes de eventos, entre outros. Tem-se como hipótese que para o arranjo do hip hop metropolitano há a formação de um micro circuito espacial de horizontalidades, amarrado por círculos espaciais de cooperação da resistência - círculos ascendentes de informação (SILVA, 2010) com as posses e o intercâmbio entre os grupos e instituições do movimento e destas com outros agentes da sociedade, algo que ocorre do nível local até o nível regional com o calendário tático de eventos.

A expansão do movimento pelas periferias de diversas cidades brasileiras implicou em aumento de complexidade do circuito e, assim, de seus círculos de cooperação no território.

Pensando nesse dado, enfoca-se a articulação entre as militâncias municipais na RMC e no seu entorno: eventos, encontros, projetos, oficinas, discussões, e toda sorte de intercâmbios, compreendendo ainda os meios de informação do hip hop, que demonstram a complexidade na circulação de informação de baixo pra cima em torno da cultura das ruas na Região (Figura 3). 
Uso do território na região metropolitana de Campinas: o que se mostra no inventário da cultura hip hop (2005)

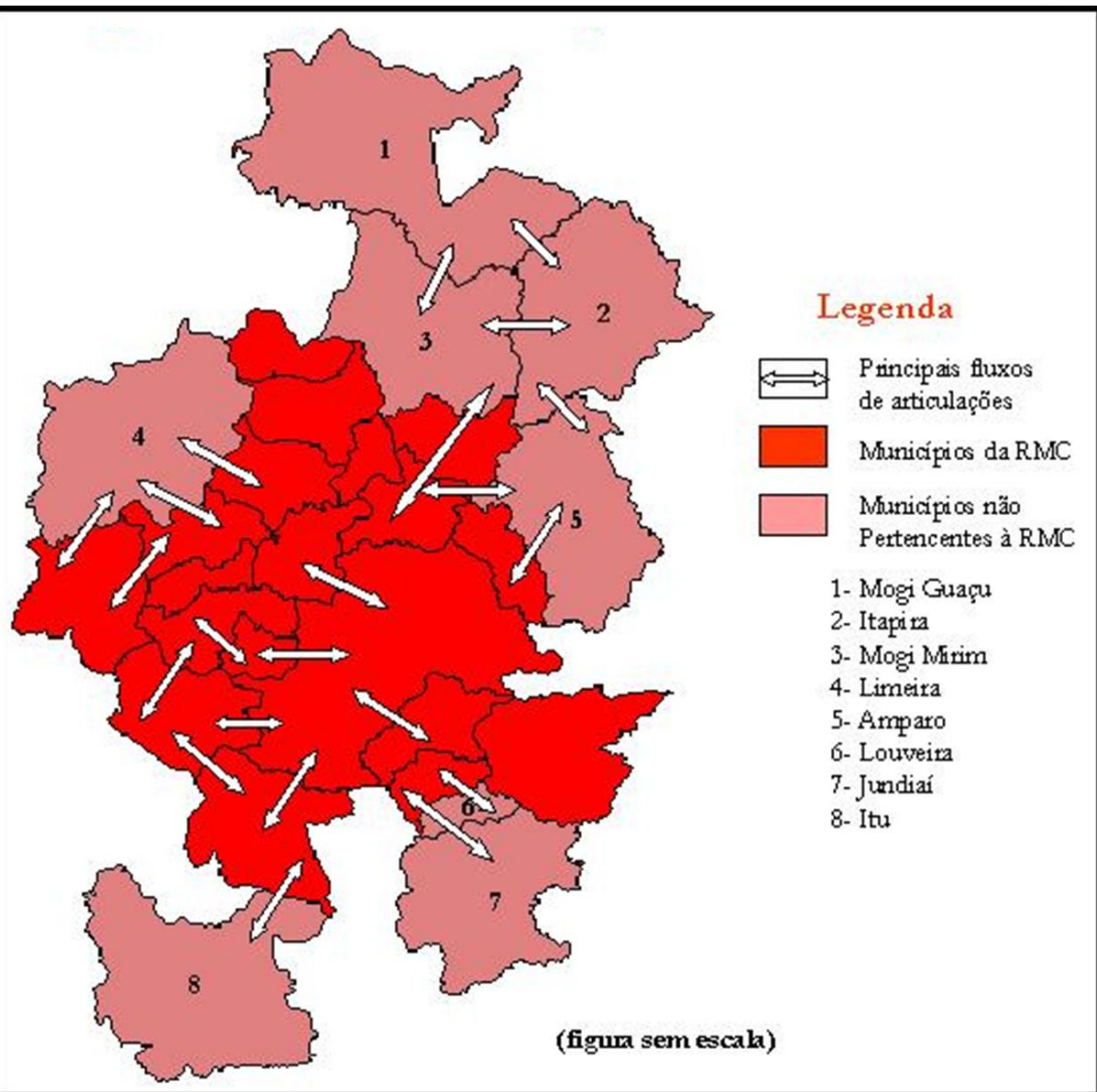

Figura 3: Articulação entre as militâncias hip hop municipais na Região Metropolitana de Campinas e entorno 1997-2005.

Elaboração Cartográfica: Cristiano N. Alves e Alcides M. Neto

Esse circuito compreenderia redes de abrangências, naturezas e superposições diversas, cuja estrutura em nada tem a ver com a compartimentação territorial metropolitana, com relações de contiguidade determinando-se sobre 0 arranjo organizacional que oficializa a RMC. Prova disso são as relações que as cidades da RMC mantêm com cidades que estão "fora" da região, como Limeira, Amparo, Piracicaba, Jundiaí e Salto.

\section{REPERCUTINDO O INVENTÁRIO: O CIRCUITO INFERIOR DA ECONOMIA E O HIP HOP NA RMC}

Para a análise da economia urbana e regional do terceiro mundo SANTOS (2004), propõe uma abordagem partindo de dois circuitos da economia, o superior e o inferior. O conjunto dos circuitos representa a cidade como um todo, em sua dinâmica, bem como a sua relação com outras cidades. Segundo o autor supracitado, o circuito superior é constituído pelo setor bancário, de exportação, de 
Uso do território na região metropolitana de Campinas: o que se mostra no inventário da cultura hip hop (2005)

logística e de indústrias e serviços modernos, enquanto o circuito inferior se constitui: "essencialmente por formas de fabricação de capital não intensivo, pelos serviços não modernos a varejo e pelo comércio não moderno e de pequena dimensão" (SANTOS, 2004, p. 40), um pequeno comércio de abrangência local e regional. Acredita-se que essa abordagem seja útil para entender como se dá a interação entre o circuito hip hop e a economia urbana na região de Campinas.

No ano de 2005, na RMC, existiam dez lojas especializadas em artigos hip hop que podiam ser divididas em lojas de artigos hip hop e lojas especializadas em rap/ música negra (Figura 4)

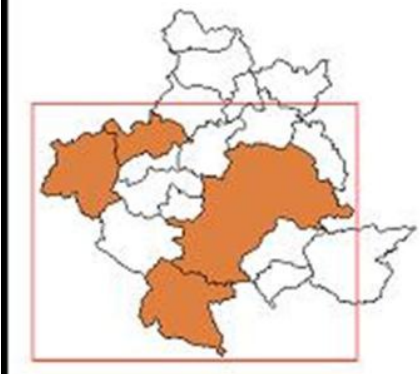

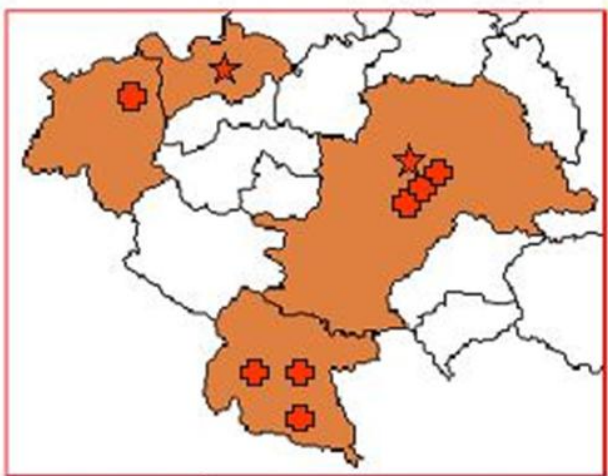

(figura sem escala)
Legenda

Lojas especializadas em artigos hip hop emgeral

Lojas especializadas em rap/black

Figura 4: Distribuição das lojas especializadas em hip hop na Região Metropolitana de Campinas 2005.

Elaboração Cartográfica: Cristiano N. Alves e Alcides M. Neto.

Além das lojas especializadas, os artigos hip hop eram encontrados dispersos em lojas de outros segmentos e nos camelôs, presentes em maior ou menor grau nos centros das cidades da RMC. Tinha-se entre os locais de comércio, os arredores na Rua Treze de Maio ou o camelódromo do Terminal Central, ambos em Campinas; as bancas próximas ao Terminal Rodoviário de Americana, ou em frente ao Supermercado Paulista em Monte Mor. Não existia uma banca especializada em hip hop, mas artigos como bonés, camisetas e CDs eram encontrados em maior ou menor quantidade em várias bancas, custando de $50 \%$ até $20 \%$ do preço dos similares vendidos nas lojas. Podem-se encontrar CDs de grupos de rap consagrados até grupos que estão começando, muitos da região. 
Uso do território na região metropolitana de Campinas: o que se mostra no inventário da cultura hip hop (2005)

Os artigos hip hop eram encontrados também nas feiras itinerantes que acontecem pelos bairros das cidades ${ }^{11}$, com itens semelhantes aos encontrados nos camelôs sendo vendidos.

Destaca-se ainda toda a rede de serviços ativada a partir da realização dos eventos hip hop: há o aluguel do local, da aparelhagem de som, há o comércio de alimentos e bebidas, contratação de seguranças, trabalho de divulgação, o que, por vezes, envolve arte gráfica, em cartazes e similares, além do cachê de grupos de rap, crews, entre outros.

Entende-se que as redes ativadas nos eventos hip hop guardam íntima relação com o circuito inferior da economia. Configuram-se a partir desse arranjo, atividades baseadas no trabalho intensivo e numa organização caseira, com capitais reduzidos, assalariamento não obrigatório e relações diretas e pessoais com a clientela (algo entrevisto nas lojas de artigos hip hop e nos camelôs) com empregos, muitas vezes temporários, como no período das festas de final de ano e preços submetidos à discussão.

Nessas redes, ou nesse circuito, manifesta-se o "mercado socialmente necessário" (RIBEIRO, 2005, p. 107), animado por "uma vida de relações resistente e tenaz", que pautado em trocas simbólicas, tem potencial para resistir ao mercado hegemônico, e o faz: resiste.

\section{OS EVENTOS ARTÍSTICOS DO HIP HOP METROPOLITANO: O DIREITO À CIDADE E O USO DO ESPAÇO PÚBLICO}

$\mathrm{Na}$ origem do hip hop, a cultura e os ideais de revolução se confundem. Dentre um dos principais valores defendidos está aquele que prevê que o segregado tenha consciência de seu papel ativo na sociedade. Para provocar mudanças o hip hopper deve conhecer sua história, seus direitos e deveres, sobretudo, por meio da arte enquanto expressão política, reivindicar seu espaço, usar o seu lugar, exercer sua condição cidadã, um pressuposto para a mudança, chamada pelos seus militantes de revolução pela consciência.

\footnotetext{
11 Em Paulínia, por exemplo, abrigavam-se iniciativas de rappers locais, que fazem grafites em camisetas vendidas por cerca de $R \$ 15,00$. A elaboração dos grafites dura pouco mais de 1 hora e a venda acontece na base do boca a boca.
} 
Uso do território na região metropolitana de Campinas: o que se mostra no inventário da cultura hip hop (2005)

A cultura hip hop propicia, principalmente, o resgate do espaço público (escasso nas áreas periféricas que, em geral, têm em locais como os botecos uma das poucas alternativas de lazer). Esse resgate ocorre de maneira simbólica, como no caso do grafite, que se organiza pela cidade em "sistemas com uma lógica de guerrilha" (SILVEIRA JUNIOR, 1991, p. 30) ou, de maneira concreta, com a utilização da rua, de escolas ou de praças para realização de ensaios de break ou rap, palestras, além da construção ou refuncionalização de locais (públicos ou não) para abrigar posses, casas do hip hop, bibliotecas, entre outros.

Como lembra Antas Junior (1996), a degradação das periferias, aliada à intensificação das formas de lazer passivo como a televisão, implicam em que "o local de residência (a casa e o bairro)" (Idem, p. 75) proporcionem cada vez menos oportunidades de lazer.

Assim sendo, a seguir apresenta-se as informações relativas ao inventário dos eventos hip hop na RMC. Destaca-se que a cultura hip hop, entre outros aspectos, surge como alternativa para a carência de bens e serviços de cultura e lazer nas áreas periféricas. Seu calendário compreende uma série de eventos artísticos, muitos deles, anônimos aos olhares externos condicionados pela grande mídia, mas de grande importância, na medida em que, baseados em critérios de acessibilidade, propiciam que indivíduos com pouca oportunidade de lazer tenham um lugar de encontro, uma situação de uso em locais que são seus por direito: os espaços públicos da cidade, cada vez mais pensados para poucos, cada vez mais um direito de poucos.

\begin{tabular}{|c|}
\hline A CULTURA HIP HOP E OS EVENTOS ARTÍSTICOS \\
REGIÃO METROPOLITANA DE CAMPINAS (2005) \\
\hline Americana \\
É consenso entre a militância local que Americana é pouco propícia à \\
realização de eventos hip hop. Aponta-se entre os motivos a falta de apoio por \\
parte da administração municipal e a discriminação para com o hip hop, \\
muitas vezes associado à violência. \\
Reflexo das dificuldades e apesar da forte presença do hip hop na
\end{tabular}


Uso do território na região metropolitana de Campinas: o que se mostra no inventário da cultura hip hop (2005)

cidade, Americana não conta com casas de shows ou eventos regulares de hip hop. Nos últimos dois anos a militância local organizou quatro eventos, realizados na Casa da Criança de Americana, no Ginásio e numa escola do Bairro São Luis. Entre os eventos ocorreu o Primeiro Festival da Cultura Hip Hop de Americana ${ }^{12}$, que contou com oficinas e apresentações dos elementos do hip hop, palestras sobre drogas e DST.

\section{Campinas}

Campinas conta com eventos regulares que já se tornaram referência no cenário do hip hop nacional e que acontecem em concordância com outros eventos da região. A cidade abriga o Hip Hop em Trânsito, um fórum de discussões realizado desde 1997 e que reúne militantes do hip hop e do movimento negro de todo o Brasil. O evento não tem local definido e já aconteceu em espaços como o Externato São João, a Comunidade dos Vicentinos e o Paço Municipal, todos no centro da cidade. A cada ano discutese um tema diferente, tais como o racismo, a violência urbana, a velha escola do hip hop, a condição da mulher negra, entre outros.

A cidade abriga ainda o Encontro de Hip Hop do Interior, que ocorre desde 1999 na semana internacional do hip hop. Além dos eventos regulares a cidade é palco de inúmeros outros ${ }^{13}$, que abrangem a cidade como um todo desde o centro até as suas periferias.

\section{Cosmópolis}

A militância local cita entre os problemas para uma maior articulação, a falta de integração entre os hip hoppers, que não se organizam de uma maneira conjunta para a realização de suas atividades. Com a falta de unidade entre os militantes do lugar e consequente perda de força de reivindicatória, perdura outro problema: a pouca abertura por parte da prefeitura municipal para com o movimento, que no máximo concede alvará para utilização de um espaço público para eventos hip hop.

\footnotetext{
${ }^{12}$ O Festival aconteceu em setembro de 2004 na Escola Pinki do Bairro São Luís.

${ }^{13}$ Como por exemplo, o Rap em Ação, realizado na Pedreira do Chapadão e o Hip Hop na Concha.
} 
Uso do território na região metropolitana de Campinas: o que se mostra no inventário da cultura hip hop (2005)

\begin{abstract}
Assim sendo, os eventos na cidade ocorrem de maneira esporádica, grande parte em espaços privados no centro, como galpões, que são utilizados para abrigar em especial shows de $\operatorname{rap}^{14}$.

A despeito dos problemas, a militância de Cosmópolis consegue organizar em média oito eventos abertos por ano, parte deles em conjunto com hip hoppers de Artur Nogueira ${ }^{15}$ realizados na Praça Chico Mendes e na Praça do Rodrigo ${ }^{16}$, em geral contando com arrecadação de alimentos e agasalhos para as famílias carentes da cidade. Estima-se que cada show realizado na praça custe aproximadamente quinhentos reais, correspondentes ao aluguel do som, divulgação e contato com grupos de rap, breakers ou grafiteiros entre outros. Vale citar que grande parcela dos gastos são arcados pelos próprios hip hoppers, que dificilmente conseguem patrocínio.
\end{abstract}

\title{
Hortolândia
}

Na cidade não existem muitos locais para apresentações hip hop. Um dos poucos é o Shopping Metropolitano, cujo aluguel para eventos hip hop é pago pela prefeitura, mediante pedido formal. Apesar disso a militância local organizou 90 shows desde 1997, quase todos em espaços públicos. Para distribuir tais eventos pela cidade os hip hoppers a dividem no centro e outras quatro regiões.

\section{Indaiatuba}

Os eventos hip hop ocorrem de maneira esporádica em escolas, praças e ruas da cidade. Entre os pontos de encontro dos hip hoppers há a Praça do Guri, na Morada do Sol.

A militância local aponta ainda como principal problema para o

\footnotetext{
${ }^{14}$ Os shows em locais privados reuniam grupos de diversas cidades do Estado com portaria cobrada na faixa de $5,00 \mathrm{R} \$$ a $8,00 \mathrm{R} \$$, e organizados por equipes especializadas em eventos, atuantes em outras cidades, como Limeira, não necessariamente ligadas ao circuito hip hop.

${ }^{15}$ Em virtude da pouca presença hip hop, Artur Nogueira, cidade componente da RMC não foi inserida no presente inventário. O município não possui grupos de rap, grafiteiros ou breakers, restringindo-se as suas manifestações hip hop à apresentações eventuais, organizadas em especial pela militância de Cosmópolis.

${ }^{16}$ A praça recebe apresentações de rap duas vezes por ano, sendo no restante do ano usada para eventos de outros gêneros como música pop ou pagode.
} 
Uso do território na região metropolitana de Campinas: o que se mostra no inventário da cultura hip hop (2005)

desenvolvimento de suas ações a pouca união entre os hip hoppers, problema que segundo eles vem sendo minimizado por meio de um maior diálogo entre as diversas orientações do hip hop indaiatubano ${ }^{17}$.

Outro problema que de acordo com a militância local vem diminuindo, é a discriminação para com o hip hop na cidade, que vem conseguindo gradativamente uma maior abertura e respeito por parte da população. Para que o reconhecimento aumente, a militância local pontua a necessidade de se apresentar da melhor maneira, sem tumultos e primando pela qualidade artística, como no show de inauguração do teatro municipal, realizado pela Secretaria Municipal de Cultura, que contou com apresentação de grupos de rap da cidade.

\section{Jaguariúna}

Conta com vários locais para shows e que podem ser utilizados pelos hip hoppers, como o Parque Santa Maria, o Centro Cultural e o Espaço Azul, todos da prefeitura municipal. Aproveitando esses locais, a militância de Jaguariúna organiza, em média, três eventos por ano, congregando hip hoppers da cidade e da região. Vale citar que a presença dos hip hoppers tem destaque no Festvida, evento anual realizado no município desde 1998.

\section{Monte Mor}

Os hip hoppers esclarecem que para a realização de eventos no município o apoio é pequeno, resumindo-se a ajuda de comerciantes e moradores dos próprios bairros. Nos últimos quatro anos, dez eventos hip hop foram organizados em Monte Mor, em geral contando com a apresentação de grupos locais juntamente com grupos de fora. Entre os locais utilizados, temos o galpão da igreja católica do Bairro Nova Alvorada, escolas do Parque do Café e Bela Vista. Nesses eventos, segundo os hip hoppers, é comum a presença de jovens pedindo alimentos e nessa via ocorreu ainda na cidade, a

\footnotetext{
${ }^{17}$ As divergências entre a militância hip hop pode ser verificada em temas diversos como a relação com grupos de outras cidades, a aproximação com partidos políticos, o conteúdo das letras dos raps, ou a presença das mulheres no rap, como no caso do grupo Opinião Feminina, formado só por garotas e que foi vítima de discriminação por parte de alguns grupos da cidade.
} 
Uso do território na região metropolitana de Campinas: o que se mostra no inventário da cultura hip hop (2005)

organização de shows fechados, para arrecadar alimentos para pessoas carentes do município.

\section{Nova Odessa}

A reduzida militância local lembra que não existe "o povo do hip hop" em Nova Odessa. Nesse escopo são poucos os eventos hip hop na cidade, realizados na Praça Central, em geral duas vezes por ano.

\section{Paulínia}

Os hip hoppers assinalam a dificuldade em realizar eventos de hip hop no município que acontecem com mais frequência apenas em época de eleições. Um dos poucos espaços para a realização de shows é o salão da câmara municipal, que mediante reserva pode ser utilizado, contando com aparelhagem básica de som.

$\mathrm{Na}$ cidade não há evento regular de hip hop. O que mais se aproxima do hip hop, com abertura para as suas manifestações, é o Festival da Música e do Adolescente de Paulínia (FEMAP).

\section{Pedreira}

De acordo com a militância local, o hip hop encontra pouco apoio na cidade, o que dificulta a organização de eventos e projetos comunitários. Pedreira conta com um Centro de Cultura mantido pela prefeitura municipal, mas que não tem abertura para eventos hip hop.

Contra a falta de apoio para organizar eventos, os rappers da cidade apelam para o contato pessoal e a ajuda de conhecidos e comerciantes ${ }^{18}$ que emprestam aparelhagem de som, participam da divulgação dos shows, cedem locais para ensaios, entre outros.

\footnotetext{
${ }^{18}$ Entre os comerciantes que apoiam o movimento, estão donos de bares, gráficas, açougues, padarias entre outros.
} 
Uso do território na região metropolitana de Campinas: o que se mostra no inventário da cultura hip hop (2005)

\section{Santa Bárbara D’Oeste}

A militância local organizou cerca de trinta eventos hip hop desde 1999. É comum a utilização de praças $^{19}$ para shows abertos que costumam reunir hip hoppers de outras cidades. O calendário hip hop municipal tem dois eventos regulares: o Conscientiza, realização conjunta da militância da zona sul e da zona leste, e o Hip Hop Contra a Fome ${ }^{20}$, que acontece na Praça da Migração, zona leste barbarense, já há dois anos, ambos reunindo nomes de expressão do hip hop estadual.

\section{Sumaré}

Destaca-se pelos eventos que abriga. Entre os eventos regulares, os Encontros Regionais de Hip Hop, realizados anualmente desde 1998 e que consistem em apresentações dos elementos da cultura hip hop, além da arrecadação de alimentos para famílias carentes da cidade. O evento, que ocorre em locais como o clube E.C.A. - Sumaré, reúne, por ano, em média cinco mil pessoas e arrecada cerca de duas toneladas de alimentos. Calculase que tenham sido organizados cerca de setenta eventos hip hop na cidade nos últimos sete anos, entre eventos públicos (predominantes) e em locais fechados.

\section{Valinhos}

Nos últimos três anos os hip hoppers locais organizaram alguns eventos, buscando integrar a militância da cidade e divulgar a cultura hip hop. Como parte dessa orientação, o primeiro evento do dia da Consciência

\footnotetext{
${ }^{19}$ Como exemplo de praças que abrigam esses eventos, há a Praça da Migração, no Jardim Pérola e a Praça do Jardim Santa Rita, entre outras. Faz parte da tática, a utilização das praças, explica a militância barbarense, por se tratarem de locais visíveis em que os eventos podem ser acompanhados inclusive pelos moradores das proximidades. Os hip hoppers da zona leste lembram que diminuiu significativamente a perseguição sofrida há alguns anos, quando foram alvos de represálias por parte da polícia que por vezes os proibiram de ensaiar nas praças da cidade, devido à reclamação da vizinhança. Em 2005, afirmavam os hip hoppers, a afetação dava lugar à curiosidade por parte dos moradores, que já se habituaram aos eventos realizados no entorno, os quais reúnem consideráveis públicos, sem indícios de brigas ou tumulto.
}

${ }^{20}$ A exemplo do Hip Hop em Trânsito em Campinas, o Hip Hop Contra a Fome tem um tema a cada ano, que serve de fio condutor para as discussões a serem postas. O tema de 2004 foi "Zumbi e a consciência negra". 
Uso do território na região metropolitana de Campinas: o que se mostra no inventário da cultura hip hop (2005)

Negra em Valinhos foi realizado pelos ativistas do hip hop, em 2003, na Praça Washington Luís, no centro. A organização desses eventos continuou no ano de 2004, com quatro shows de grande porte ${ }^{21}$, realizados em locais como 0 Museu Municipal, reunindo cada um deles cerca de 1.500 pessoas, além da participação de grupos de rap da cidade na Festa do Figo, tradicional evento do calendário municipal.

\section{Vinhedo}

Os eventos, recentes na cidade, acontecem de maneira esporádica em locais como o galpão da prefeitura municipal, não havendo para tais eventos uma estimativa de periodicidade. Espera-se ainda em 2005 incluir o hip hop na programação da Festa da Uva, parte do calendário municipal.

Fonte: Campo de informação primária

A partir das informações reunidas, observa-se que, exceto em Cosmópolis, onde predominam eventos em locais privados, em todas as outras cidades inventariadas se sobressaem os eventos hip hop em locais públicos. Estes somam cerca de cinquenta ao ano nas cidades inventariadas sem contar os eventos realizados em Campinas.

Isto implica dizer que a apropriação do espaço público (o uso) vem sendo uma das principais táticas do hip hop metropolitano. Trata-se de um calendário de eventos, ora desenvolvido sob a influência apenas de redes fundadas no contato pessoal e de estrutura rizomática, numa dinâmica aleatória, ora erigidos sob a influência de órgãos que põem em relevo a institucionalização do movimento, tais quais as posses e famílias de rap.

Entende-se que uma intensa apropriação do espaço público pela cultura hip hop seria um ponto de partida para legitimação das vozes que hoje, nas cidades, clamam por seus direitos e vislumbram outro planejamento urbano, mais concatenado ao direito à cidade, conforme propõe Lefebvre (1969), autor que vê o futuro da arte na sociedade urbana e propõe que a cidade, ela mesma, seja

\footnotetext{
${ }^{21}$ Entre os grupos que participaram desses eventos figuram o Facção Central, que realizou o único show com portaria, e o Expressão Ativa, ambos da capital paulista.
} 
Uso do território na região metropolitana de Campinas: o que se mostra no inventário da cultura hip hop (2005)

concebida como obra, que, segundo ele, não existe: "sem uma sucessão regulamentada de atos e ações, de decisões e de condutas, sem mensagens e sem códigos (...) sem coisa, sem uma matéria a ser modelada, sem uma materialidade prático sensível, sem um lugar, um campo, um meio...." (LEFEBVRE, 1969, p. 49).

De acordo com a reflexão, a restituição do sentido da obra viria da arte, mais precisamente, do lúdico: "o princípio da reunião em seu conteúdo" (LEFEBVRE, 1969, p. 21), capaz de "dar ao tempo prioridade sobre o espaço - não sem considerar que o tempo vem se inscrever e se escrever, num espaço - por apropriação acima do domínio" (Idem, p. 122). O direito a cidade seria a "forma superior dos direitos: direito a liberdade, a individualidade na socialização, a habitat e ao habitar. O direito a obra... (Ibidem, p. 124). Cristalização substantivada pelo encontro, pelo lúdico e sua centralidade, conferida por suas mensagens, valores e possibilidades.

\section{CONSIDERAÇÕES FINAIS}

Acredita-se que as relações de contiguidade, assim como o grau de articulação dado pelos órgãos hip hop podem ajudar ainda no entendimento da maior espessura do circuito hip hop em Campinas, Sumaré e Hortolândia, bem como do grande número de grupos de rap em Indaiatuba: são quatro cidades com grandes periferias, constituídas por bairros operários cuja configuração territorial facilita a aglomeração.

Chama a atenção o fato de que essa espécie de mancha hip hop corresponde ao eixo da pobreza da RMC identificado por Cano e Brandão (2002), acionando-se assim a problemática da Metrópole Corporativa e fragmentada (SANTOS, 1990), na medida em que se vê o florescimento do hip hop nas áreas "esquecidas" da metrópole. Este eixo vem seguindo a Rodovia Anhanguera, desde o Bairro Capela, no sul de Vinhedo, passando pela área sul de Campinas, Hortolândia e Sumaré, focos importantes do hip hop metropolitano. Outro dado importante é que essa espécie de mancha hip hop se sobrepõe aos maiores corredores de trânsito intermunicipal de passageiros do estado de São Paulo, que envolve, entre outras, as linhas que ligam Campinas à Hortolândia e Sumaré. 


\section{ALVES, C.N. \\ Uso do território na região metropolitana de Campinas: o que se mostra no inventário da cultura hip hop (2005)}

Ressalta-se que por meio da ação de um pequeno número de indivíduos, por vezes se estrutura os rumos que o circuito toma num dado município. Reforça-se assim o papel do indivíduo enquanto sujeito ativo, sendo importante a ação de cada um para o desenvolvimento das atividades hip hop.

Em torno do circuito de eventos hip hop o lúdico e seus desdobramentos, possibilitam a comunicação entre os de baixo: os eventos se interligam, articulam-se as pessoas que deles participam. É no show de rap, no curtir um som, fazer um som, no fazer a divulgação de CD, acompanhar uma batalha de break: é no "trocar ideia" que surgem os grupos, as crews e seus grafiteiros, as inquietações, o querer saber de diversas formas, do não pode ser assim ao tem que ser de outro jeito.

Nos eventos hip hop que acontecem em locais como centros comunitários, praças, bosques, ruas ou escolas, promove-se o debate sobre a ação deste ou daquele órgão hip hop, ouve-se a divulgação do próximo evento nas vinhetas do DJ, acompanha-se a grafitagem. Nesses lugares dinamizados em torno da arte como contestação, convivem as crianças, os idosos, os hip hoppers e os de passagem, enfim, o povo do bairro e o povo do centro, nesse momento o povo da cidade, e então, a arte restitui o sentido da obra: "oferece múltiplas figuras de tempos e espaços apropriados: não impostos, não aceitos por uma resignação passiva, mas metamorfoseados em obra" (LEFEBVRE, 1969, p. 106).

Falar dos eventos como reunião, faz pensar a respeito dos lugares de encontros dos homens lentos: onde estariam esses encontros? Quais seriam? Em que situações? Além dos encontros mais próximos, no bairro, ou, como dizem alguns moradores das periferias no "centro", lá na cidade (muitos deles não se sentem mesmo parte da cidade).

Durante os trabalhos de campo observou-se uma série de encontros, comunicações e ações do hip hop, uma voz que comunica o direito à cidade, e outras vozes de natureza distintas, mas que trazem a mesma comunicação.

Entre essas vozes têm-se entidades como: lideranças de bairro, Movimento Negro, igrejas, camelôs, perueiros, Movimento dos Trabalhadores Rurais Sem Terra (MST), Movimento dos Trabalhadores Sem Teto (MTST), ativistas dos movimentos anti-globalização, movimento punk, entre outros. Todos pedindo uma outra cidade, mais igualitária. 
Uso do território na região metropolitana de Campinas: o que se mostra no inventário da cultura hip hop (2005)

Quais desses encontros fazem com que essas pessoas tenham contato com a cidade, aquela cidade onde mora e com as cidades vizinhas? Quais as comunicações estabelecidas a partir desses encontros? Quais as ações possíveis e concretizadas a partir dessas comunicações? Eis aqui uma vasta e rica agenda de pesquisa cara aos estudos geográficos.

\section{REFERÊNCIAS}

ANDRADE, E.N. O movimento negro juvenil: um estudo de caso sobre os rappers de São Bernardo do Campo. Dissertação em Educação. Faculdade de educação - Universidade de São Paulo. São Paulo-SP. 1996.

ANTAS JUNIOR, R.M. Globalização, urbanização e lazer. Revista Experimental. São Paulo-SP, n 1, p. 69-76. 1996.

BÉTHUNE, C. Sites technologiques, panoramas sonores : les univers esthétiques du rap et de la musique techno. Volume 1, Paris, $1: 2$, p. 43-57, 2002.

CAIADO, A.S.C. Campinas. In: CANO, Wilson e BRANDÃO, Carlos A. A região Metropolitana de Campinas: urbanização, economia, finanças e meio ambiente. Vol. 2. Campinas-SP: Editora Unicamp, 2002.

CALOGIROU, C. Le Florida, lieu musical entre banlieue et centre-ville: l'exemple des rappeurs agenais. Les Annales de La Recherche Urbaine, Paris, $n^{\circ} 70$, p. 48-57, 1996.

CANO, W. e BRANDÃO, C.A. A região Metropolitana de Campinas: urbanização, economia, finanças e meio ambiente. Campinas-SP: Editora Unicamp, Vols. 1 e 2, $2002 \mathrm{a} / \mathrm{b}$.

CORREA, R.L. O espaço urbano. São Paulo-SP: Ática, 1989.

CRAMPTON, J.W. e KRYGIER, J. An Introduction to critical cartography. ACME: An International E-Journal for Critical Geographies, Los Angeles, 4 (1), p. 11-33, 2006.

GOMES, R.L. Território usado e movimento hip hop: cada canto um rap, cada rap um canto. Dissertação (mestrado em Geografia), Universidade Estadual de Campinas, 2012. 
Uso do território na região metropolitana de Campinas: o que se mostra no inventário da cultura hip hop (2005)

ISNARD, H. O espaço do geógrafo. Rio de Janeiro, Boletim Geográfico. № 258,259, p. 5-16, 1978.

KEYES, C.L. At the crossroads: Rap music and its African nexus. Etnomusicology, London. Vol. 40, p. 222-248. 1996.

LEFEBVRE, H. O direito à cidade. São Paulo-SP: Documentos, 1969.

LENCIONI, S. Observações sobre o conceito de cidade e urbano. Geousp, São Paulo, n²4, p. 109-123, 2008.

LOJKINE, J. O estado capitalista e a questão urbana. São Paulo: Martins Fontes, 1977.

LOURENÇO, M.L. Cultura, arte, política e o Movimento Hip Hop. Curitiba-PR: Chaín, 2002.

MESTRE, A.P.; FONSECA, H.R. O Plano Diretor e a regionalização como ferramenta do planejamento de Campinas: uma análise da região do Jardim Campo Belo. Boletim Campineiro de Geografia, Campinas, vol. 1, № 1, p 31-46, 2011.

MOREIRA, R. Da região à rede e ao lugar: a nova realidade e o novo olhar geográfico sobre o mundo. Etc, Espaço, Tempo e Crítica, Rio de Janeiro-RJ, $n^{\circ 1}$, vol. 1, p. 55-70, 2007.

POCHMANN, M. Renda, emprego e pobreza. In: Livro Verde: desafios para a gestão da Região Metropolitana de Campinas. Campinas-SP: Unicamp, 2002.

PRATES, D.X. Repensando a periferia no período popular da história. Relatório de qualificação de mestrado. Rio Claro-SP, UNESP, 2004.

RIBEIRO, A.C.T. Território usado e humanismo concreto: o mercado socialmente necessário in SILVA, Catia A. et all. Formas em crise: utopias necessárias. Rio de Janeiro-RJ: Arquimedes Edições, p. 93-111. 2005.

ROCHEFORT, M. Regionalização e rede urbana. Ra'E Ga, Curitiba, n7, p. 115-121, 2003.

RUBIN, C. Le rap est-il soluble dans la chanson française? Volume 1, Paris, $3: 2$, p. 29-42, 2004. 
Uso do território na região metropolitana de Campinas: o que se mostra no inventário da cultura hip hop (2005)

SANTOS, M. O espaço geográfico como categoria filosófica. Terra Livre, São Paulo, n. 5, p. 9-20, 1988.

- São Paulo, Metrópole Corporativa. Revista de Administração Pública, São Paulo. Vol. 23, n 1, p. 103-111, 1989.

1990.

Metrópole corporativa e fragmentada. São Paulo-SP: Nobel,

. O território e o saber local: algumas categorias de análise. Cadernos IPPUR, Rio de Janeiro, ano XIII, n² 2, p. 15-26, 1999.

p. 21-22, 2002 .

. O tempo nas cidades. Ciência e Cultura, São Paulo, vol. 54,n²

.O espaço dividido. São Paulo-SP: Edusp, 2004.

SILVA, J.C.G. Rap na cidade de São Paulo: música, etnicidade e experiência urbana. 1998. Tese (doutorado em Ciências Sociais) - Universidade Estadual de Campinas-SP, Departamento de Ciências Sociais IFCH-Unicamp. Campinas.

- Juventude e segregação urbana na cidade de São Paulo: os números da vulnerabilidade juvenil e a percepção musical dos rappers. Ponto.Urbe (USP), São Paulo, v. 1, p. 01-12, 2007.

SILVA, A.B. A cidade de São Paulo e os círculos de informações. Ciência Geográfica. Ano XIV, Vol. XIV, nำ1, janeiro/dezembro, AGB-Bauru, p.24-30, 2010.

SILVEIRA, M.L. Uma situação geográfica: do método à metodologia. Revista Território, São Paulo, ano IV, nº. 6, p. 21-27, 1999.

SILVEIRA, N.E. Superfícies alteradas: uma cartografia dos grafites na cidade de São Paulo. 1991. Dissertação (mestrado em Antropologia) - Universidade Estadual de Campinas-SP, Departamento de Antropologia IFCH-Unicamp. Campinas. 